\title{
Herbicides in Camps Bay (Cape Town, South Africa), supplemented
}

\author{
Cecilia Y. Ojemaye ${ }^{\mathrm{a}}$, Chionyedua T. Onwordi ${ }^{\mathrm{a}, \mathrm{b}}$, Daniela M. Pampanin ${ }^{\mathrm{c}}$, Magne O. Sydnes ${ }^{\mathrm{c}}$, Leslie Petrik ${ }^{\mathrm{a}, *}$ \\ a Environmental and Nano Science Group, Department of Chemistry, University of the Western Cape, Cape Town, South Africa \\ b Department of Chemistry, Faculty of Science, Lagos State University, LASU, P.O. Box 0001, Ojo, Lagos, Nigeria \\ c Department of Chemistry, Bioscience and Environmental Technology, Faculty of Science and Technology, University of Stavanger, NO-4036 Stavanger, Norway
}

\section{H I G H L I G H T S}

- In 2017 sewage released into Camps Bay, Cape Town was nine fold more than rainfall.

- Five herbicides were found in seawater, sediments and marine biota from Camps Bay.

- The chemical load in sewage was not removed by a $3 \mathrm{~mm}$ screen pretreatment step.

- The chemical signature found in marine biota was linked to herbicides in sewage.

- Dilution of sewage by seawater did not prevent bioaccumulation of herbicides.

\section{A R T I C L E I N F O}

\section{Article history:}

Received 2 December 2020

Received in revised form 18 February 2021

Accepted 19 February 2021

Available online 25 February 2021

Editor: Damia Barcelo

\section{Keywords:}

Herbicides

Sewage

Seawater

Sediment

Marine biota

Persistent organic pollutant

\section{G R A P H I C A L A B S T R A C T}
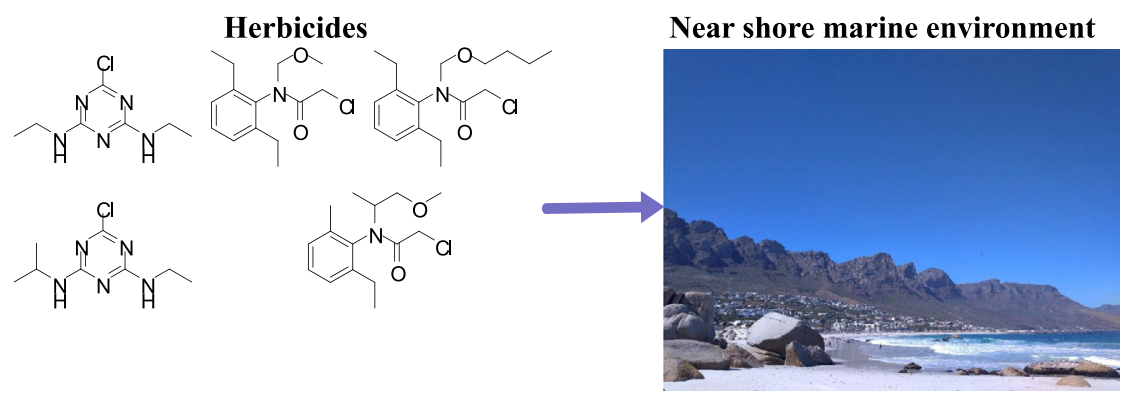

\begin{abstract}
A B S T R A C T
During 2017 the herbicides alachlor, atrazine, butachlor, metolachlor, and simazine were detected in water samples, beach sediments and marine biota collected at Camps Bay, Cape Town, South Africa. During that period, the annual rain catchment record was $77,000 \mathrm{~m}^{3}$, whereas the volume of chemically laden sewage discharged via the marine outfall was $693,500 \mathrm{~m}^{3}$ making the marine sewage outfall by far the most predominant source for these herbicides in the bay. The chemical load in the discharged sewage was not removed by the applied pre-treatment step, which only uses a $3 \mathrm{~mm}$ screen to eliminate plastic, paper, rags and other foreign materials. After passing through the Camps Bay pump station, the sewage is released to the bay at the following GPS position $33^{\circ} 56^{\prime}$ 42.214" S $18^{\circ} 21^{\prime} 59.257^{\prime \prime} \mathrm{E}$ (Colenbrander et al., 2021) and at a discharge depth of $23 \mathrm{~m}$ and $1497 \mathrm{~m}$ from the beach. In our study the presence in marine biota of atrazine and simazine were taken as being indicative of the chemical signature of the sewage being released through the outfall, since these compounds were detected previously in the sewage prior to discharge. To our knowledge, our studies of the herbicides in diverse benthic organisms found in the near shore environment of Camps Bay are the first of their kind for this Western Cape region.
\end{abstract} (c) 2021 Elsevier B.V. All rights reserved.

\section{Introduction}

Last year we published a paper describing the presence of five herbicides, namely alachlor, atrazine, butachlor, metolachlor, and simazine,

\footnotetext{
* Corresponding author.

E-mail address: lpetrik@uwc.ac.za (L. Petrik).
}

in seawater, beach sediments and marine biota collected at Camps Bay, Cape Town, South Africa (Ojemaye et al., 2020a). The major findings showed that the five herbicides were detected in concentrations ranging from below the limit of detection ( $<\mathrm{LOD}$ ) to $4.2 \mathrm{ng} / \mathrm{L}$ in seawater, < LOD to $45.3 \mathrm{ng} / \mathrm{g}$ dry weight $(\mathrm{dw})$ in sediments, $<$ LOD to $157.8 \mathrm{ng} / \mathrm{g} \mathrm{dw}$ in marine organisms, and between $12.3 \mathrm{and} 87.0 \mathrm{ng} / \mathrm{g}$ $\mathrm{dw}$ in seaweed. Results of the ecological risk assessment for acute and 
chronic risks, calculated using the US Environmental Protection Agency method (US EPA, 2016), showed a possible threat to the near shore environment from the sewage released by the marine outfall, as the herbicide contamination in biota posed a low to high ecotoxicological risk to marine organisms. Hazard quotients and carcinogenic risk caused by herbicide pollution in Camps Bay seawater were above the acceptable levels, indicating that these chemicals pose adverse health effects, should an average sized human ( $70 \mathrm{~kg}$ ) consume any of the analysed marine species on a daily basis (daily consumption of $54 \mathrm{~g}$ ), over a lifetime period (life expectancy of 70 years). In our study, we measured the impact and calculated the risk factors for several benthic organisms (mussels, limpet, sea urchin, and seaweeds), considerably extending the knowledge about the impacts on marine biota. The study drew the attention of the Environmental Management Department in Cape Town, which resulted in a communication by (Colenbrander et al., 2021). Although Colenbrander et al. agreed with our findings, they objected to the point that the predominant source of the herbicides in Camps Bay is the marine sewage outfall. We agree with Colenbrander et al. (2021) that the pollution of the marine environment of Camps Bay with herbicides requires urgent attention. We choose to exercise our right of reply to their rebuttal of our work in the present communication, in which we will address several points to supplement and further contextualize our previously published findings.

\subsection{Herbicides in the environment}

Herbicides in the environment represent a potential hazard to living organisms due to their lipophilic properties, which allow bioaccumulation in biota, and their resistance to degradation (Aparecida et al., 2013; Jurado et al., 2011; Wyss et al., 2006; Ying and Williams, 2000; Yu et al., 2016). The majority of herbicide monitoring studies have focused on freshwater, such as lakes, rivers and reservoirs, with a particular focus on organochlorine compounds (Ccanccapa et al., 2016b, 2016a; Horak et al., 2021; Masiá et al., 2013; Miller et al., 2019; Palma et al., 2014; Papadakis et al., 2015; Tadeo et al., 2008), with a few exceptions see for example (Riascos-Flores et al., 2020; Yang et al., 2019). A large portion of the herbicide residues reach the ocean through agricultural runoff, atmospheric transportation, and sewage discharge (Campo et al., 2013; Knopp et al., 2016; Münze et al., 2017; Pandit et al., 2006; Stamatis et al., 2010). Upon discharge of these chemicals into themarine environment, they are dispersed into the water, and may accumulate in sediments and marine organisms. Exposure to a herbicide such as atrazine has been associated with severe health problems in humans, such as low fetus and heart weight, birth defects, limb defects, neurologic diseases, cancers, urinary defects, dermatologic diseases, and respiratory disorders (ATSDR, 2003; Ochoa-Acuña et al., 2009; Pathak and Dikshit, 2012; Rinsky et al., 2012). It is therefore important to fully understand their distribution and concentration in all matrices of the marine environment (Amdany et al., 2014; Tiemann, 2008).

\subsection{Raw sewage}

In the Cape Town Outfalls Monitoring Programme: Surveys made in 2015/2016 (CSIR, 2017), which was commissioned by the Coastal Management Branch of the City of Cape Town, it is stated that the Camps Bay marine outfall "comprises a pre-treatment works, where sand and grit are removed and the wastewater is screened $(3 \mathrm{~mm})$ to remove plastic, paper, rags and other foreign material. The effluent is then discharged to the marine receiving environment". Since a $3 \mathrm{~mm}$ screen or filter is unable to remove microbes, nutrients, inorganic or organic chemical pollutants, apart from the minute amounts that are adsorbed to larger particles being filtered out in addition to the filter itself, the sewage being discharged can be defined as raw from a chemical contamination point of view. Only gross objects are removed from the sewage plume during this pre-treatment. Therefore, the sewage effluent, which is released into a marine protected area, has a high bacterial and chemical load. The CSIR report (2017) describes frequent exceedances in the levels of Escherchia. coli and fecal streptococci on the Camps Bay beach and it is also noted that on occasions it has exceeded the Blue Flag guidelines (Blue Flag, 2020). The bacterial load due to fecal contamination along the beaches in Cape Town has also been confirmed in 2019 (COCT, 2019), which summarises the results of samples taken from 90 locations spread out over $307 \mathrm{~km}$ of the Cape Peninsula's coastline. In 2019, Camps Bay was accordingly given a rating of "fair" (COCT, 2019). The ranking of "fair" means that the estimated risk of illness per exposure is ranked as $<8,5 \%$ gastrointestinal illness risk, the Enterococci level $(\mathrm{cfu} / 100 \mathrm{~mL})$ is given as $<185$, and the E. coli (cfu/100 mL) as $<500$, on average across all seasons. Hence, there is good evidence that the beach at Camps Bay is intermittently affected by sewage effluent plumes making landfall.

\section{The monitoring}

All the experimental details related to sample preparation, and analytical protocols used for the environmental monitoring of herbicides are provided in Ojemaye et al. (2020a). The LOQ and LOD values also appear therein in addition to the analytical data. The marine biota included limpets (Cymbula granatina), mussels (Mytilus galloprovincialis), sea urchins (Parachinus angulosis), seaweeds (Ulva sp.and Codium fragile). The sample size at each GPS site for each species was mussels $(n=30)$; sea urchins $(n=15)$; limpets $(n=25)$; seaweed $(n=500 \mathrm{~g})$. Each species from each location was separately sampled, but we bulked the specific units of each organism together as sampled at each GPS location given in Table 1. The minimum, maximum, mean values, and standard deviations were thus not calculated as individual units of each species. The results were qualitative for the population of benthic organisms sampled as the sample size was quite small. The study gave spatial variation based on each sample site (Ojemaye et al., 2020a) but did not show temporal variation, as only one sampling campaign was possible.

The GPS coordinates for the Camps Bay sampling positions can be found in Table 1. The GPS positions given in Table 1, are representative, showing at which exact location specific marine organisms (MO), sediment (SD), beach sand (BS), and seawater (SW) were collected. Seven different locations were sampled for MO, three different locations for SW and two different locations for sediment/beach sand.

\subsection{Study area}

"Camps Bay is a relatively small bay, about $850 \mathrm{~m}$ wide. The bay is bounded by rocky headlands at Maidens Cove and opposite Camps Bay Drive. The beach at Camps Bay is popular for bathing in summer" (CSIR, 2017). Camps Bay is not within Table Bay but in relatively close proximity and to the south of Table Bay, thus swept by predominantly northerly currents. The current direction is variable and it is influenced by wind direction, wave height and temperature differentials etc. The

Table 1

Coordinates for Camps Bay sampling locations.

\begin{tabular}{lll}
\hline Location & Coordinates & \\
\hline BS1 & $33^{\circ} 57^{\prime} 09.9^{\prime \prime} \mathrm{S}$ & $18^{\circ} 22^{\prime} 34.3^{\prime \prime} \mathrm{E}$ \\
SD2 & $33^{\circ} 57^{\prime} 10.1^{\prime \prime} \mathrm{S}$ & $18^{\circ} 22^{\prime} 32.8^{\prime \prime} \mathrm{E}$ \\
SW3 & $33^{\circ} 57^{\prime} 09.7^{\prime \prime} \mathrm{S}$ & $18^{\circ} 22^{\prime} 30.5^{\prime \prime} \mathrm{E}$ \\
SW4 & $33^{\circ} 57^{\prime} 07.8^{\prime \prime} \mathrm{S}$ & $18^{\circ} 22^{\prime} 30.1^{\prime \prime} \mathrm{E}$ \\
SW5 & $33^{\circ} 57^{\prime} 06.4^{\prime \prime} \mathrm{S}$ & $18^{\circ} 22^{\prime} 31.5^{\prime \prime} \mathrm{E}$ \\
MO6 & $33^{\circ} 57^{\prime} 11.0^{\prime \prime} \mathrm{S}$ & $18^{\circ} 22^{\prime} 30.9^{\prime \prime} \mathrm{E}$ \\
MO7 & $33^{\circ} 57^{\prime} 10.8^{\prime \prime} \mathrm{S}$ & $18^{\circ} 22^{\prime} 27.6^{\prime \prime} \mathrm{E}$ \\
MO8 & $33^{\circ} 57^{\prime} 09.2^{\prime \prime} \mathrm{S}$ & $18^{\circ} 22^{\prime} 26.4^{\prime \prime} \mathrm{E}$ \\
M09 & $33^{\circ} 57^{\prime} 08.8^{\prime \prime} \mathrm{S}$ & $18^{\circ} 22^{\prime} 27.9^{\prime \prime} \mathrm{E}$ \\
MO10 & $33^{\circ} 57^{\prime} 09.6^{\prime \prime} \mathrm{S}$ & $18^{\circ} 22^{\prime} 28.9^{\prime \prime} \mathrm{E}$ \\
MO11 & $33^{\circ} 57^{\prime} 09.3^{\prime \prime} \mathrm{S}$ & $18^{\circ} 22^{\prime} 29.5^{\prime \prime} \mathrm{E}$ \\
M012 & $33^{\circ} 57^{\prime} 10.5^{\prime \prime} \mathrm{S}$ & $18^{\circ} 22^{\prime} 29.0^{\prime \prime} \mathrm{E}$ \\
\hline
\end{tabular}


CSIR (2017) reports that although there is significant variability, currents generally flow in a northerly direction from Camps Bay towards Green Point and beyond, hence the marine outfall discharges from Camps Bay are likely to be swept past Green Point and up the coast towards Namibia. The velocity of the circulation on the surface is different from the velocity of circulation deeper down in the water column which results in longer residence times of water within Table Bay and Camps Bay (CSIR, 2017). It is to be noted that there are few residential or urban areas to the south of Camps Bay, apart from Llandudno, a small community which also has a wastewater treatment plant that discharges partially treated effluent into the sea. A revised map with the exact position of the marine outfall is depicted in Fig. 1. Fig. 1 shows the proximity of the marine outfall to Camps Bay beach, which is a popular bathing beach for residents and tourists. Camps
Bay is a relatively shallow bay and the discharge depth of the marine outfall is $23 \mathrm{~m}$, hence is not positioned in the deep ocean but very much on the coastal shelf. Inshore currents or winds may drive the sewage plume landwards and the bay then acts as a retention zone with a low turnover frequency until the prevailing weather pattern changes.

Apart from the Twelve Apostle mountain range, the mountainous contours of the geographical location would prevent ingress of watershed from the vicinal catchments into Camps Bay. The mountain range isolates the suburb from the rest of the city. The sewer catchment area for Camps Bay serves the Clifton, Camps Bay and Bakoven areas (CSIR, 2017) and is isolated from the other sewage catchment areas of the city. In both respects, Camps Bay can therefore be described as isolated. Moreover, apart from the ocean, Camps Bay shares no rivers or open

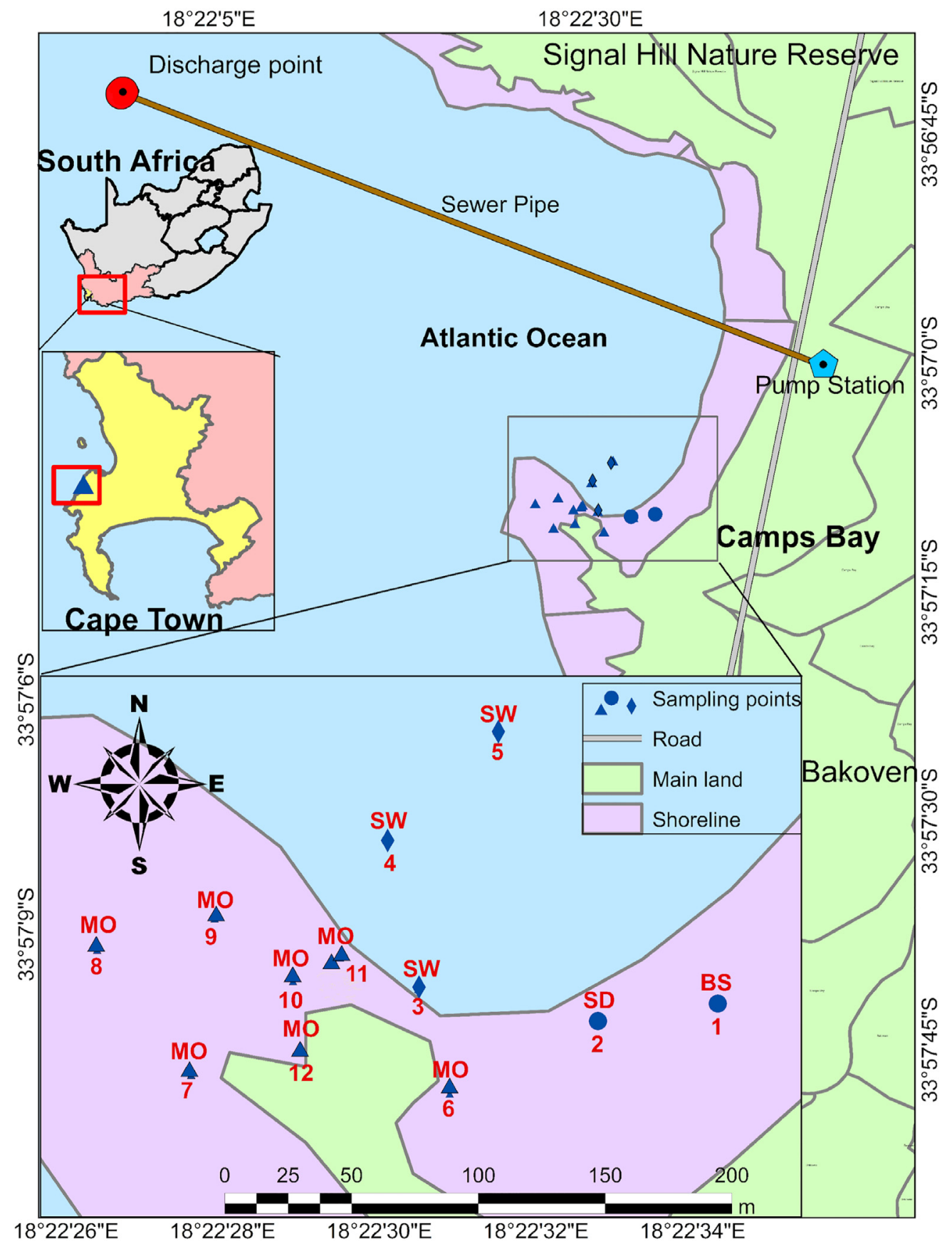

Fig. 1. Map showing sampling points and the marine outfall discharge point (MO: marine organisms; SW: seawater; SD: sediment; BS: beach sand). 
Table 2

Coordinates of storm water discharge points and urban streams on Camps Bay beach.

\begin{tabular}{ll}
\hline Feature & Coordinates \\
\hline Camps Bay marine outfall discharge point & $18^{\circ} 21^{\prime} 59.257^{\prime \prime} \mathrm{E}$ \\
& $33^{\circ} 56^{\prime} 42.214^{\prime \prime} \mathrm{S}$ \\
Camps Bay excess stormwater run-off point & $18^{\circ} 22^{\prime} 38.21^{\prime \prime} \mathrm{E}$ \\
& $33^{\circ} 57^{\prime} 9.018^{\prime \prime} \mathrm{S}$ \\
Main Camps Bay stormwater discharge point & $18^{\circ} 22^{\prime} 29.744^{\prime \prime} \mathrm{E}$ \\
& $33^{\circ} 57^{\prime} 13.246^{\prime \prime} \mathrm{S}$ \\
Non-perennial urban stream discharge point & $18^{\circ} 22^{\prime} 33.83^{\prime \prime} \mathrm{E}$ \\
& $33^{\circ} 57^{\prime} 19.561^{\prime \prime} \mathrm{S}$ \\
\hline
\end{tabular}

water bodies with the rest of Cape Town, as can be seen from the most recent Inland Water Quality Report (Day et al., 2020), which covers water quality trends in the major rivers and open water bodies in the city, over a five-year period from April 2015 to March 2020.Table 2 shows the GPS position of Camps Bay excess storm water run-off point and main storm water discharge points.

\section{Results and discussion}

\subsection{Exact coordinates for the marine outfall in Camps Bay}

After passing the Camps Bay pump station, the sewage deriving from the suburb is released to Camps Bay at the following GPS position $33^{\circ} 56^{\prime}$ 42.214“ S $18^{\circ} 21^{\prime} 59.257^{\prime \prime}$ E (Colenbrander et al., 2021), at a discharge depth of $23 \mathrm{~m}$ and $1497 \mathrm{~m}$ from the beach (CSIR, 2017). We would like to thank Colenbrander et al. for providing the exact coordinates for the marine outfall in Camps Bay. This is the first time that these GPS coordinates have been made public, which also explains why the position for the marine outfall was slightly misplaced in our previous publication (Ojemaye et al., 2020a). However, misplacing the position of the marine outfall on the map does not compromise our findings, since we never intended to sample at the exact position of the outfall, but in the near shore environment. Possibly, the accurate position for the marine outfall is further away from our sampling position providing even better potential for dilution of the sewage plume before reaching our sampling stations.

\subsection{Chemical background information}

The study analysed for the chemical signature of the sewage in the marine biota, and thus we chose to test for the herbicides atrazine and simazine in the near shore environment, as these compounds were definitely present in the sewage being discharged in the marine environment of Camps Bay, according to the CSIR (2017) report, hence were indicative of chemically contaminated sewage. The chemical load in the sewage discharged in Camps Bay has been communicated in a CSIR report (CSIR, 2017), which reported 49 different chemical compounds (including the herbicides atrazine and simazine) being present at detectable levels in sewage from the Camps Bay pump station. In their study, sewage samples from the sewage pump station in Camps Bay in addition to two other locations were analysed by Eurofins/ Omegam laboratory in the Netherlands (an accredited laboratory from the Dutch Accreditation Council).
Numerous organochlorine pesticides as well as organophosphate and nitrogenous pesticides were reported. Among the reported analytes were the two herbicides, viz. atrazine and simazine (Table 3 ), in addition to many hydrocarbons and pharmaceuticals. The results from the CSIR report (CSIR, 2017) represent good baseline data for our study. Since the population of Camps Bay has been relatively steady over the last five-six years, it is unlikely that the chemical composition of the sewage would change dramatically over time. The findings in the CSIR report is also supported by another study where numerous persistent contaminants were identified in the influent and effluent of five wastewater treatment plants in Cape Town, including Zandvliet, Scottsdene, and Bellville plants (Swartz et al., 2018a, 2018b).

Our recent study was focused on the conditions in Camps Bay and the samples analysed are therefore collected within the bay. In order to get an overview of the conditions in Camps Bay in terms of pollution by herbicides, it is not required to sample reference samples from a clean site. Previous studies have shown that it would be very difficult to find a clean reference site without contamination by sewage (high concentration of fecal bacteria indicating sewage contamination) in the vicinity of Cape Town that could provide a comparable reference sample (COCT, 2019; CSIR, 2017).

\subsection{Concentration of herbicides in water samples, beach sediments, and marine biota}

Our data presented in Table 3 clearly represents a link between the herbicides in the sewage discharged via the Camps Bay pump station and the presence of the same herbicides in the Camps Bay seawater and marine biota. (Ojemaye et al., 2020a).

As seen from the concentrations of atrazine and simazine in seawater samples compared to the ones detected in the sewage (Table 3 ), there is a significant dilution factor in the bay after release to the environment (concentration of the two herbicides at the Camps Bay pump station compared with the detected concentration of the two compounds in seawater samples (Table 3). As a summary of our previously reported findings, the five herbicides were detected in concentrations ranging from below the limit of detection ( $<$ LOD) to $4.2 \mathrm{ng} / \mathrm{L}$ in seawater, < LOD to $45.3 \mathrm{ng} / \mathrm{g}$ dry weight $(\mathrm{dw})$ in sediments, $<$ LOD to $157.8 \mathrm{ng} / \mathrm{g} \mathrm{dw}$ in marine organisms, and between 12.3 and $87.0 \mathrm{ng} / \mathrm{g}$ $\mathrm{dw}$ in seaweed (for detailed analytical data see Ojemaye et al., 2020a). The bioaccumulation of the studied herbicides in the marine biota, for example mussels (Table 3), shows that the ocean dilution of untreated sewage is not an adequate mitigation measure. The concentration detected in benthic organisms show long term exposure and bioaccumulation trends. The data obtained from the analytical instrumentation is quantitative based upon the LOQ and LOD, but the results are qualitative for the population of benthic organisms sampled as the sample size was quite small, and the study does not show temporal variation. Our work was aimed at demonstrating evidence of risk, not providing evidence of absolute causality. Nevertheless, the chemical signature in the samples and the chemical signature in the sewage matched, showing a link to the marine sewage outfall. E. coli is universally used as an indicator of fecal pollution, and in our study atrazine and simazine were taken as being indicative of the chemical signature of the sewage being released through the outfall, since they were detected previously in the sewage (CSIR, 2017).

Table 3

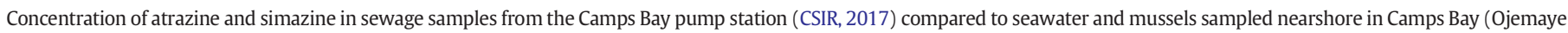
et al., 2020).

\begin{tabular}{|c|c|c|c|}
\hline Compound & Sewage at Camps Bay pump station (CSIR, 2017) & Seawater (Ojemaye et al., 2020a) & Mussels (average $^{a}$ ) (Ojemaye et al., 2020a) \\
\hline Atrazine & $<80 \mathrm{ng} / \mathrm{L}$ & $1.58 \pm 0.8 \mathrm{ng} / \mathrm{L}$ & $35.3 \pm 0.1 \mathrm{ng} / \mathrm{g} \mathrm{dw}^{\mathrm{a}}$ \\
\hline Simazine & $<200 \mathrm{ng} / \mathrm{L}$ & $4.18 \pm 0.0 \mathrm{ng} / \mathrm{L}$ & $157.8 \pm 0.1 \mathrm{ng} / \mathrm{g} \mathrm{dw}^{\mathrm{a}}$ \\
\hline
\end{tabular}

a Average value in nanograms per gram dry weight (ng/g dw) for samples of Mussels (Mytilus galloprovincialis). 


\subsection{Origin of the herbicides}

The data in the CSIR report clearly show that herbicides are present in the sewage being discharged via the marine outfall in Camps Bay (CSIR, 2017). Yet Colenbrander et al. (2021) claimed that the herbicides detected in Camps Bay enter the bay by urban run-off, urban streams, and domestic grey water.

During 2017, the rain catchment record for Camps Bay was 77,000 $\mathrm{m}^{3}$ (Colenbrander et al., 2021). Fig. 2 gives an overview of the distribution of rain over the period (Williams et al., 2020).

In the same period, the average sewage discharge volume was 1900 $\mathrm{m}^{3}$ per day (personal communication with Colenbrander), which in total gives $693,500 \mathrm{~m}^{3}$ for the full year of 2017 . The volume of highly contaminated sewage entering Camps Bay in 2017 was thus nine times higher than the total rainfall in the catchment for the year. There is also no evidence presented in the communication by Colenbrander et al. (2021) that would explain the equivalent concentration of herbicides in storm water as an alternative source to sewage. And even if it were so, considering the prevailing drought at the time of sampling and the very large difference in volume between the annual rainfall versus annual contaminated sewage effluent discharge, the storm water due its insignificant volume would at most contribute a fraction of the herbicide concentration reported in the sewage. With this information at hand the marine sewage outfall in the bay is considered the predominant source of herbicides entering the bay.

\subsection{Ecological relevance of herbicide contamination}

Our published study showed bioaccumulation of all herbicides in biota i.e. mussels, limpets, sea urchins and seaweeds (except for metolachlor and butachlor in limpets, and alachlor and metolachlor in sea urchins), (Ojemaye et al., 2020a, 2020b). As previously emphasised, herbicides can cause a broad range of toxicities (Carlberg, 2014). Herbicide contamination of surface waters is known to compromise both structure and biodiversity of invertebrate communities (Ashauer, 2016; Beketov et al., 2013; Liess and Von Der Ohe, 2005). Therefore, there is a worldwide concern due to their negative effects on the environment at large.

As an example, Münze et al. (2017) observed considerable ecological effects of herbicides present in concentrations both above and below the regulatory threshold levels, concluding that wastewater treatment plants need to be improved for the degradation of pesticides. Finally, the presence of pesticides in wastewater treatment plant effluents have been linked to ecological effects on macro invertebrate communities, demonstrating the high ecological relevance of this kind of contamination (Ashauer, 2016; Bunzel et al., 2013).

\section{Discussion}

Although studies of elemental composition in benthic organisms such as mussels (Mytilus galloprovincialis) sampled along the South African coastline are limited, high consumption risks were noted because of unacceptable levels of $\mathrm{Al}, \mathrm{Cr}, \mathrm{Co}, \mathrm{Zn}$, As, and I in mussel samples collected at greywater outlets in the Cape Town area (Waterfront, Hout Bay) and Durban ((Nekhoroshkov et al., 2021). According to Firth et al. (2019), As and $\mathrm{Pb}$ concentrations in M. galloprovincialis exceeded some South African regulatory limits. Petrik et al. (2017) sampled various biota including mussels (M. galloprovincialis), near Granger Bay, Cape Town and found 15 pharmaceutical and household chemicals bioaccumulated in the selected marine organisms. The source of these compounds was ascribed to the marine outfall in proximity to the Granger Bay site in Green Point, Cape Town. We previously sampled commercially-exploited, wild-caught small and medium pelagic fish including snoek (Thyrsites atun), bonito (Sarda orientalis), hottentot (Pachymetopon blochii), and panga (Pterogymnus laniarius) for target chemical compounds (pharmaceuticals and personal care products, perfluoroalkyl compounds and industrial chemicals) (Ojemaye and Petrik, 2019). Moreover, five indicator herbicides were also detected in all the fish sampled, which could potentially pose a carcinogenic risk to humans who consume these fish over an extended period of time (Ojemaye et al., 2020b). Notably, all fish sampled contained high levels of the selected chemical compounds in their fillets, liver, gills and intestines, showing that the same chemicals we had found in the sewage effluent (Swartz et al., 2018a, 2018b) were found in the marine environment.

The City of Cape Town's own studies from over 10,000 sample bacterial tests at 90 sites along $307 \mathrm{~km}$ of the Peninsula coastline, have shown gross fecal pollution in many coastal sites around the Peninsula (City of Cape Town: Know your coast, 2019). Thus, it is common cause that there are few sites around the Peninsula that are uncontaminated by sewage. Hence, it was not feasible within the study limits to find a control site without fecal and thus associated chemical contamination

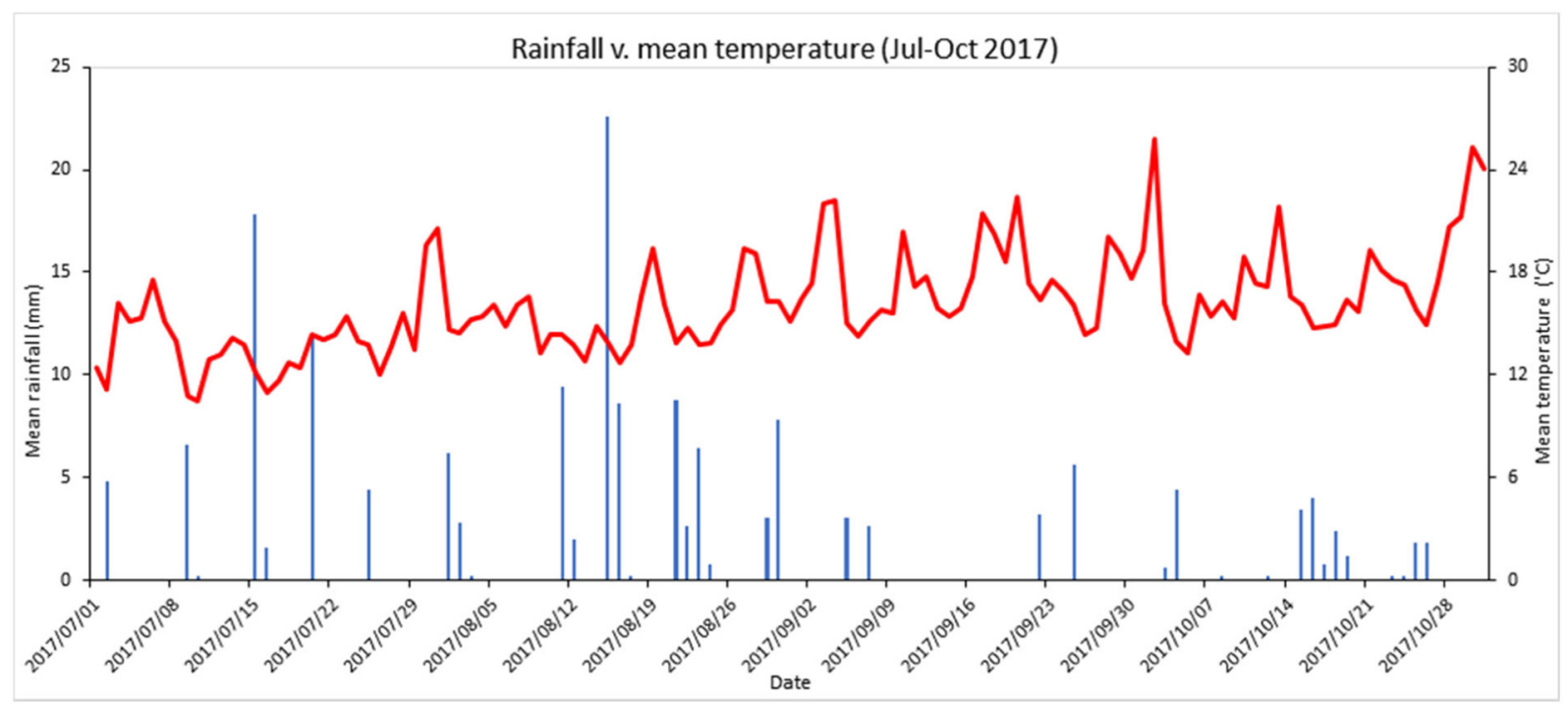

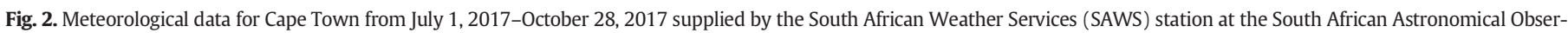
vatory (SAAO), located approximately $23 \mathrm{~km}$ ESE of the study site. 
around the Cape Peninsula. Our study controls were the herbicide compounds detected and reported by the CSIR (2017). The authors of the rebuttal demanded that our study should extend to a much wider geographical area. Such studies are available for metal contaminants in mussels in Saldanha Bay versus Danger Bay, which was chosen as a remote control site (Bezuidenhout et al., 2015). Yet their studies showed that metal concentrations were higher at the control site than at the sampling sites Hence control sites in remote locations can also bring surprises.

All selected compounds were detected in benthic samples from the near shore marine environment of a Blue Flag beach in a Marine Protected Area at Camps Bay. The high levels of herbicides detected in the marine biota are indicative that the dilution of the sewage by the ocean in Camps Bay does not adequately prevent bioaccumulation by the marine organisms. It is likely, based upon the enhanced chemical signature in Camps Bay organisms, that the retention time of the sewage in Camps Bay is longer than at Green Point (Petrik et al., 2017). The large volume of "pretreated" sewage discharged from the marine outfall at Green Point and the very high volumes of partially treated effluent discharged from other waste water treatment plants may very well influence the contamination measured at Camps Bay, but determining this influence was beyond the scope of the study. To our knowledge no oceanographic study of the region has determined chemical signatures in local seawater to date, and detailed determination of chemical signatures including persistent contaminants such as herbicides are not normally part of oceanographic surveys.

The Camps Bay study focused specifically upon the herbicides as these are banned chemicals evidently being discharged via a marine outfall into a Marine Protected Area. In our study we calculated the ecological risk factors of the herbicides for several benthic organisms, considerably extending the knowledge about the environmental impacts of herbicides upon benthic organisms found in the near shore environment. By studying the chemical signatures we aimed to elucidate linkages between marine health and anthropogenic impacts. The results show that it is necessary to keep a register of banned herbicides, and carefully monitor any illicit sales and herbicide used in the municipality.

Colenbrander et al. (2021) claim in their rebuttal that the herbicides and other contamination in the Bay are due to stormwater, urban runoff and grey water discharges. If this were really the case, there would be a high public health hazard and many ill people, since it would imply that Camps Bay urban land is grossly contaminated by chemically contaminated faeces through open defecation, and illegal disposal of chemical and pharmaceutical waste. This is not the case as an inspection of the suburb would reveal. The Camps Bay suburb is populated by wealthy, rate paying citizens who do not tolerate open defecation, illegal waste disposal or raw sewage spills in their suburb and are very quick to take matters in hand where such spills have occasionally occurred due to burst sewerage pipes. According to a personal communication from D. Colenbrander their department is not aware of Camps Bay beach being officially closed to the public for any reason (except during lockdown due to COVID 19 regulations) over the last 10 years or more. Their department has closed Glen Beach adjacent to Camps Bay beach on two occasions, one for a burst sewer main in a road above Glen Beach and the second for a flocculent discharge from the potable water works on Kloof Nek. We assume from the communication, that this is the limit of land based sewage contamination due to faulty sewerage infrastructure over 10 years. Sources other than the marine outfall might partially be contributing to herbicide levels measured in the sampled sites and organisms, but considering the prevailing drought at the time of sampling and the very large difference in volume between annual rainfall versus annual contaminated sewage effluent discharge in 2017, the likelihood for a significant herbicide contribution from rainfall, or any urban streams (which are noted to be perennial), or run-off from domestic use, or stormwater, or backwash, etc. is very slight. During 2017, as discussed, the volumes of discharge from these urban run-off and stormwater points was at least 10 times lower than the volume of sewage, which was highly contaminated with diverse chemicals, being discharged through the marine outfall. Thus, even if these stormwater discharge points were closer to our sampling sites, the much smaller volume of rainwater which may have flowed out of these discharge points would have made a negligible contribution to the overall contamination we detected. But, Camps Bay boasts of its Blue Flag status. The Blue Flag status of Camps Bay beach is only granted for 3 months of the year during summer and only applies to half of the beach. Nevertheless, according to the Blue Flag criteria for beaches, criterion 9 states that no industrial, waste-water or sewage-related discharges should affect the beach area. Thus, should high concentrations of these herbicides be discharged from urban streams, domestic grey-water or urban run-off, as Colenbrander et al. (2021) claim, this presents a problem for the City to attain Blue Flag status. If these contaminants are not from the marine outfall discharging "pre-treated" sewage, then it is running from poorly managed sewerage infrastructure leaking highly contaminated domestic grey-water or urban runoff sources into the inshore "swim zone" of this beach, making it even more problematic from a community health perspective, besides contravening the requirements for Blue Flag status.

As appointed custodians of our coastal environment, the authors of the rebuttal should consider the precautionary principle, which is embedded in South Africa's Constitutional Bill of Rights (Section 24) and the National Environmental Management Act (107 of 1998). The local government's duty to incorporate this principle and adhere to this approach is furthermore emphasised in the National Guideline for the Discharge of Effluent From Land Based Sources into the Environment (2014). From our constitution, promulgated laws such as the National Environmental Management Act (107 of 1998), and guidelines, as well as local laws and international treaties that South Africa has signed, it is evident that the precautionary approach, duty of care and polluter pays principles have to be considered in terms of assessing water quality as well as in the broader scale of ecosystems health, and mitigation of the potential impacts of the marine outfalls.

\section{Conclusions}

In the period of sampling, the annual volume of contaminated sewage, being discharged through the marine outfall in Camps Bay, was about nine times greater than that from rain, run-off and stormwater entering the bay. Therefore, the marine sewage outfall is considered the predominant source of herbicide contamination entering the Camps Bay marine environment. Moreover, the applied pre-treatment of sewage using a $3 \mathrm{~mm}$ screen as filtration step does not remove chemicals from sewage. The chemical signature of atrazine and simazine found in the seawater and biota samples and their chemical signature in the raw sewage matched, showing their link to the marine sewage outfall. Our inferences were drawn from quantifying selected herbicide concentrations in seawater, sediments and marine organisms. In our published study we had concluded that the predominant origin of the herbicides that were detected in the samples collected at Camps Bay was the marine sewage outfall and in this supplement, we still maintain this is predominantly the case, based upon the relative contribution of rainfall versus sewage volumes to the bay. Despite the purported adequate dilution of sewage by the ocean according to the outfall design criteria, these herbicides pose a high ecological risk to marine biota. Thus the ocean dilution of untreated sewage is not an adequate mitigation measure. It is very important to mitigate the ecological impact of chemically laden sewage discharged into this Marine Protected Area.

\section{CRediT authorship contribution statement}

Cecilia Y. Ojemaye: Data curation, Formal analysis, Investigation, Methodology, Validation, Visualization, Writing - review \& editing. 
Chionyedua T. Onwordi: Writing - review \& editing. Daniela M. Pampanin: Writing - review \& editing. Magne 0. Sydnes: Writing review \& editing. Leslie Petrik: Conceptualization, Formal analysis, Funding acquisition, Project administration, Resources, Supervision, Writing - original draft.

\section{Declaration of competing interest}

The authors declare that they have no known competing financial interests or personal relationships that could have appeared to influence the work reported in this paper.

\section{Acknowledgments}

We gratefully acknowledge the SANOCEAN program for funding the project "Marine Sewage Outfalls - Environmental Impact Evaluation" (Research Council of Norway; Project no: 287516) and the National Research Foundation, South Africa (Project no: 118754). We thank Dr. Solomon Owolabi, Dept. of Geology, University of Fort Hare for composing the map (Fig. 1) and Mr. John Williams, Dept. of Chemistry, University of the Western Cape for drawing graphics from the SAWS data (Fig. 2).

\section{References}

Amdany, R., Chimuka, L., Cukrowska, E., Kukučka, P., Kohoutek, J., Vrana, B., 2014. Investigating the temporal trends in $\mathrm{PAH}, \mathrm{PCB}$ and $\mathrm{OCP}$ concentrations in Hartbeespoort dam, South Africa, using semipermeable membrane devices (SPMDs). Water SA 40, 425-436. https://doi.org/10.4314/wsa.v40i3.5.

Aparecida, M., de Campos Ventura-Camargo, B., Miyuki, M., 2013. Toxicity of herbicides: impact on aquatic and soil biota and human health, in: herbicides - current research and case studies in use. InTech. https://doi.org/10.5772/55851.

Ashauer, R., 2016. Post-ozonation in a municipal wastewater treatment plant improves water quality in the receiving stream. Environ. Sci. Eur. 28, 1-7. https://doi.org/ 10.1186/s12302-015-0068-z.

ATSDR, (Agency for Toxic Substances and Disease Registry), 2003. Public health statement atrazine.

Beketov, M.A., Kefford, B.J., Schäfer, R.B., Liess, M., 2013. Pesticides reduce regional biodiversity of stream invertebrates. Proc. Natl. Acad. Sci. U. S. A. 110, 11039-11043. https://doi.org/10.1073/pnas.1305618110.

Bezuidenhout, J., Dames, N., Botha, A., Frontasyeva, M.V., Goryainova, Z.I., Pavlov, D., 2015. Trace elements in mediterranean mussels mytilus galloprovincialis from the south African west coast. Ecol. Chem. Eng. S 22, 489-498. https://doi.org/10.1515/eces2015-0028.

Blue Flag, 2020. Blue Flag Marina Criteria and Explanatory Notes 2020.

Bunzel, K., Kattwinkel, M., Liess, M., 2013. Effects of organic pollutants from wastewater treatment plants on aquatic invertebrate communities. Water Res. 47, 597-606. https://doi.org/10.1016/j.watres.2012.10.031.

Campo, J., Masiá, A., Blasco, C., Picó, Y., 2013. Occurrence and removal efficiency of pesticides in sewage treatment plants of four Mediterranean River basins. J. Hazard. Mater. 263, 146-157. https://doi.org/10.1016/j.jhazmat.2013.09.061.

Carlberg, Z., 2014. Sustainable weed management for for Small and Medium-Scale Farms. National Center for Appropriate Technology 1-800-346-9140 https:/attra.ncat.org/ product/sustainable-weed-management-for-small-and-medium-scale-farms/.

Ccanccapa, A., Masiá, A., Andreu, V., Picó, Y., 2016a. Spatio-temporal patterns of pesticide residues in the Turia and Júcar Rivers (Spain). Sci. Total Environ. 540, 200-210. https://doi.org/10.1016/j.scitotenv.2015.06.063.

Ccanccapa, A., Masiá, A., Navarro-Ortega, A., Picó, Y., Barceló, D., 2016b. Pesticides in the Ebro River basin: occurrence and risk assessment. Environ. Pollut. 211, 414-424. https://doi.org/10.1016/j.envpol.2015.12.059.

COCT, (City of Cape Town), 2019. Know your coast 1-33.

Colenbrander, D., Oelofse, G., Le Roux, M., 2021. Rebuttal: Ojemaye, C. Y., Onwordi, C. T., Pampanin, D. M., Sydnes, M. O., \& Petrik, L., 2020. Presence and risk assessment of herbicides in the marine environment of Camps Bay (Cape Town, South Africa) Sci. Total Environ. doi:10.1016/j.scitot. Sci. Total Environ. https://doi.org/10.1016/j. scitotenv.2020.142576.

CSIR, 2017. Cape Town outfalls monitoring programme: Surveys made in 2015/2016. CSIR Report CSIR/NRE/ECOS/IR/2017/0035/B. (Cape Town).

Day, L., Ollis, D., Ngobela, T., Rivers-Moore, N., 2020. Water Quality Of Rivers And Open Waterbodies In The City Of Cape Town: Status And Historical Trends, With A Focus On The Period April 2015 To March 2020.

Firth, D.C., Salie, K., O'Neill, B., Hoffman, L.C., 2019. Monitoring of trace metal accumulation in two south African farmed mussel species, Mytilus galloprovincialis and Choromytilus meridionalis. Mar. Pollut. Bull. 141, 529-534. https://doi.org/10.1016/ j.marpolbul.2019.03.007.

Horak, I., Horn, S., Pieters, R., 2021. Agrochemicals in freshwater systems and their potential as endocrine disrupting chemicals: a south African context. Environ. Pollut. https://doi.org/10.1016/j.envpol.2020.115718.
Jurado, A.S., Fernandes, M.A.S., Videira, R.A., Peixoto, F.P., Vicente, J.A.F., 2011. Herbicides: the face and the reverse of the coin. An in vitro approach to the toxicity of herbicides in non-target organisms. In: Kortekamp, A. (Ed.), Herbicides and Environment https://doi.org/10.5772/550 Kroatia, pp. 3-45.

Knopp, G., Prasse, C., Ternes, T.A., Cornel, P., 2016. Elimination of micropollutants and transformation products from a wastewater treatment plant effluent through pilot scale ozonation followed by various activated carbon and biological filters. Water Res. 100, 580-592. https://doi.org/10.1016/J.WATRES.2016.04.069.

Liess, M., Von Der Ohe, P.C., 2005. Analyzing effects of pesticides on invertebrate communities in streams. Environ. Toxicol. Chem. 24, 954-965. https://doi.org/10.1897/03-652.1.

Masiá, A., Campo, J., Vázquez-Roig, P., Blasco, C., Picó, Y., 2013. Screening of currently used pesticides in water, sediments and biota of the Guadalquivir River basin (Spain). J. Hazard. Mater. 263, 98-104. https://doi.org/10.1016/j.jhazmat.2013.09.035.

Miller, T.H., Ng, K.T., Bury, S.T., Bury, S.E., Bury, N.R., Barron, L.P., 2019. Biomonitoring of pesticides, pharmaceuticals and illicit drugs in a freshwater invertebrate to estimate toxic or effect pressure. Environ. Int. 129, 595-606. https://doi.org/10.1016/j. envint.2019.04.038.

Münze, R. Hannemann, C. Orlinskiy, P., Gunold, R., Paschke, A., Foit, K., Becker, J. Kaske, O., Paulsson, E., Peterson, M., Jernstedt, H., Kreuger, J., Schüürmann, G., Liess, M., 2017. Pesticides from wastewater treatment plant effluents affect invertebrate communities. Sci. Total Environ. 599-600, 387-399. https://doi.org/10.1016/J. SCITOTENV.2017.03.008.

Nekhoroshkov, P.S., Bezuidenhout, J., Frontasyeva, M.V., Zinicovscaia, I.I., Yushin, N.S., Vergel, K.N., Petrik, L., 2021. Trace elements risk assessment for consumption of wild mussels along South Africa coastline. J. Food Compos. Anal. 98, 103825. https://doi.org/10.1016/j.jfca.2021.103825.

Ochoa-Acuña, H., Frankenberger, J., Hahn, L., Carbajo, C., 2009. Drinking-water herbicide exposure in Indiana and prevalence of small-for-gestational-age and preterm delivery. Environ. Health Perspect. 117, 1619-1624. https://doi.org/10.1289/ehp.0900784

Ojemaye, C.Y., Petrik, L., 2019. Occurrences, levels and risk assessment studies of emerging pollutants (pharmaceuticals, perfluoroalkyl and endocrine disrupting compounds) in fish samples from Kalk Bay harbour, South Africa. Environ. Pollut. 252, 562-572. https://doi.org/10.1016/j.envpol.2019.05.091.

Ojemaye, C.Y., Onwordi, C.T., Pampanin, D.M., Sydnes, M.O., Petrik, L., 2020a. Presence and risk assessment of herbicides in the marine environment of Camps Bay (Cape Town, South Africa). Sci. Total Environ. 738, 140346. https:// doi.org/10.1016/j.scitotenv.2020.140346.

Ojemaye, C.Y., Onwordi, C.T., Petrik, L., 2020b. Herbicides in the tissues and organs of different fish species (Kalk Bay harbour, South Africa): occurrence, levels and risk assessment. Int. J. Environ. Sci. Technol. 17, 1637-1648. https://doi.org/10.1007/ s13762-019-02621-y.

Palma, P., Köck-Schulmeyer, M., Alvarenga, P., Ledo, L., Barbosa, I.R., López de Alda, M., Barceló, D., 2014. Risk assessment of pesticides detected in surface water of the Alqueva reservoir (Guadiana basin, southern of Portugal). Sci. Total Environ. 488-489, 208-219. https://doi.org/10.1016/j.scitotenv.2014.04.088.

Pandit, G.G., Sahu, S.K., Sharma, S., Puranik, V.D., 2006. Distribution and fate of persistent organochlorine pesticides in coastal marine environment of Mumbai. Environment International, pp. 240-243 https://doi.org/10.1016/j.envint.2005.08.018 Pergamon.

Papadakis, E.N., Tsaboula, A., Kotopoulou, A., Kintzikoglou, K., Vryzas, Z., PapadopoulouMourkidou, E., 2015. Pesticides in the surface waters of Lake Vistonis Basin, Greece: occurrence and environmental risk assessment. Sci. Total Environ. 536, 793-802. https://doi.org/10.1016/j.scitotenv.2015.07.099.

Pathak, R.K., Dikshit, A.K., 2012. Atrazine and human health. Int. J. Ecosyst. 1, 14-23. https://doi.org/10.5923/j.ije.20110101.03.

Petrik, L., Green, L., Zackon, M., Sanusi, C.Y., Green, L., 2017. Desalination and seawater quality at Green Point, Cape Town: a study on the effects of marine sewage outfalls. 113, 1-10. https://doi.org/10.17159/sajs.2017/a0244.

Riascos-Flores, L., Bruneel, S., Van der Heyden, C., Deknock, A., Van Echelpoel, W., Forio M.A.E., De Saeyer, N., Vanden Berghe, W., Spanoghe, P., Bermudez, R., DominguezGranda, L., Goethals, P., 2020. Polluted paradise: occurrence of pesticide residues within the urban coastal zones of Santa Cruz and Isabela (Galapagos, Ecuador). Sci. Total Environ. https://doi.org/10.1016/j.scitotenv.2020.142956 142956.

Rinsky, J.L., Hopenhayn, C., Golla, V., Browning, S., Bush, H.M., 2012. Atrazine exposure in public drinking water and preterm birth. Public Health Rep. 127, 72-80. https://doi. org/10.1177/003335491212700108.

Stamatis, N., Hela, D., Konstantinou, I., 2010. Occurrence and removal of fungicides in municipal sewage treatment plant. J. Hazard. Mater. 175, 829-835. https://doi.org/ 10.1016/J.JHAZMAT.2009.10.084.

Swartz, C., Genthe, B., Chamier, J., Petrik, L., Tijani, J., Adeleye, A., Coomans, C., Ohlin, A Falk, D., Menge, J., 2018a. Emerging Contaminants In Wastewater Treated For Direct Potable Re-Use: The Human Health Risk Priorities In South Africa. VOLUME III: Occurrence, Fate, Removal And Health Risk Assessment Of Chemicals Of Emerging Concern In Reclaimed Water For Potable Reuse.

Swartz, C., Genthe, B., Chamier, J., Petrik, L., Tijani, J., Adeleye, A., Coomans, C., Ohlin, A., Falk, D., Menge, J., 2018b. Emerging Contaminants in Wastewater Treated for Direct Potable re-Use : The Human Health Risk Volume I: A Concise Research Report.

Tadeo, J.L., Sánchez-Brunete, C., González, L., 2008. Pesticides: classification and properties. In: Tadeo, J. (Ed.), Analysis of Pesticides in Food and Environmental Samples. CRC Press, pp. 1-34 https://doi.org/10.1201/9781420007756.

Tiemann, U., 2008. In vivo and in vitro effects of the organochlorine pesticides DDT, TCPM, methoxychlor, and lindane on the female reproductive tract of mammals: a review. Reprod. Toxicol. 25, 316-326. https://doi.org/10.1016/J.REPROTOX.2008.03.002.

US EPA, 2016. Technical overview of ecological risk assessment: problem formulation [WWW document]. (last Updat. 31/12/2014). URL. https://www.epa.gov/pesticidescience-and-assessing-pesticide-risks/technical-overview-ecological-risk-assessment-risk. 
Williams, J., Petrik, L., Wichmann, J., 2020. PM2.5 chemical composition and geographical origin of air masses in Cape Town, South Africa. Air Qual. Atmos. Health, 1-12 https:// doi.org/10.1007/s11869-020-00947-y.

Wyss, A., Boucher, J., Montero, A., Marison, I., 2006. Micro-encapsulated organic phase for enhanced bioremediation of hydrophobic organic pollutants. Enzym. Microb. Technol. 40, 25-31. https://doi.org/10.1016/j.enzmictec.2005.10.033.

Yang, L., Li, H., Zhang, Y., Jiao, N., 2019. Environmental risk assessment of triazine herbicides in the Bohai Sea and the Yellow Sea and their toxicity to phytoplankton at environmental concentrations. Environ. Int. 133, 105175. https://doi.org/10.1016/j. envint.2019.105175.

Ying, G.G., Williams, B., 2000. Laboratory study on the interaction between herbicides and sediments in water systems. Environ. Pollut. 107, 399-405. https://doi.org/10.1016/ S0269-7491(99)00178-5.

Yu, J., Li, X., Yang, J., Wu, Y., Li, B., 2016. Effects of simazine exposure on neuronal development-related factors in MN9D cells. Med. Sci. Monit. 22, 2831-2838. https://doi.org/10.12659/MSM.896460. 